\title{
ЛЕКСИКО-СЛОВОТВІРНІ ТИПИ ІМЕННИКІВ ІЗ СУФІКСОМ -ИЩЕ В ДАВНІЙ РУСБКОУКРАЇНСЬКІЙ МОВІ
}

\begin{abstract}
Білоусенко П. І., Меркулова О. В. Лексико-словотвірні типи іменників із суфіксом -ище в давній руськоукраїнській мові

У статті розглянуто походження суфікса -ище (-із̌с̌е) та його похідних -ovišе̌e/-evišče, -лище, нище; 3'ясовано особливості їхнього функціонування у праслов'янській та давній руськоукраїнській мові; доведено, що висока продуктивність цього форманта створила підгрунтя для зростання його активності в наступні періоди розвитку мови.

Ключові слова: іменник, суфікс, лексико-словотвірний тип, праслов'янська мова, давня руськоукраїнська мова.
\end{abstract}

Белоусенко П. И., Меркулова О. В. Лексико-словообразовательные типы имен существительных с суффиксом -ище в древнем русскоукраинском языке

В статье рассмотрено происхождение суффикса -ище (-ǐ̌̌̌) и его производных -ovišče/-evišče, лище, -нище; охарактеризованы особенности их функционирования в праславянском и древнем русскоукраинском языке; доказано, что высокая продуктивность этого форманта создала основу для возрастания его активности в последующие периоды развития языка.

Ключевые слова: имя существительное, суффикс, лексико-словообразовательный тип, праславянский язык, древний русскоукраинский язык.

Bilousenko P. I., Merkulova O.V. Lexical-derivational types of nouns with the suffix-ище in the ancient Russian-Ukrainian language.

The article deals with the origin of the suffix -ище (-išče) and its derivatives -ovišče/-evišče, -лище, нище, characterizes the peculiarities of their functioning in the Common Slavonic language and ancient Russian-Ukrainian language; it has been proved that the high productivity of this suffix laid down the basis for its increased activity in subsequent periods of language development.

Key words: noun, suffix, lexical-derivational type, Common Slavonic language, ancient RussianUkrainian language.

Суфікс -іг̌с̌е належить до числа праслов'янських інновацій [7, с. 59], був досить поширений на теренах усієї Славії [12, с. 226; 10, с. 135], репрезентований у літературних мовах і діалектах. Ряд мовознавців (А. Мейе, А. Брюкнер, Я. Отребський, О. Франк та ін.) [див. огляд думок : 6, с. 55] вважає, що східнослов'янський суфікс -із̌с̌е та південнослов'янський -ište $\epsilon$ результатом об'єднання -isko з суфіксом -jo. У західних слов'ян -isko зберіг первинну форму. В. Ташицький, I. Лось, Г. Улашин, Ф. Оберпфальцер та інші дотримувалися думки, що -išče походить від давнього ад'єктивного суфікса -istъ, ускладненого -jo, a суфікс -isko - результат контамінації -išče i -bsko. У наступних спеціальних дослідженнях [див. 10;6] лінгвісти загалом поділяють цей погляд на генезу суфікса -ище. Однак Ф.Славський не вважає питання походження згаданого афікса остаточно з'ясованим і висловлює думку, що цей формант походить із праслов'янського прикметникового суфікса -bskъ (i.є. -rsko, розширеного суфіксом -jo, а початкове -i- в -isko (субстантивована форма n. singularia прикметника на -bskъ) та в -išče виникло з основ дієслів на -і-: тип *lovi-sko; *lovi-šče від *loviti [11, т.1, c. 96-97 ]. 
Обстежений матеріал праслов'янської доби підтверджує думку Ф. Славського [див. 11, т.1, с. 95-96] про те, що основною функцією суфікса -із̌če в цей період було творення л $о \kappa a m u$ в найменувань від субстантивних чи дієслівних (дуже часто непохідних) основ, однак трапляються й деривати з подвійною мотивацією.

Значну кількість іменників складають девербативи на позначення місця, яке виникло в результаті дій людини чи природних сил: *garišče (ЭССЯ VI 101) "місце в лісі, випалене пожежею, згарище" (*garati); *gojišče (195) "місце для відгодовування домашньої худоби" (*gojiti “відгодовувати”); *grebišče (VII 109) “могила, кладовище” (*grebti); *jbgrišče (VIII 211-212) “арена, амфітеатр; гра, розвага, видовище; вечірка” (*jbgrati); *katišče (IX 163) "місце на березі річки або в лісі, де взимку звозять заготовані для сплаву колоди і звідки навесні скочують їх у річку або звозять у поселення" (*katjati, *katiti); *kladišče (177) "місце поховання, кладовище; склад” (*klasti, *klado); *leč(idl)išče (XIV 175) "місце для лікування" від *lečidlo "ліки"; *lětišče (XV 7) "місце, де проводять літо" (*lětiti “проводити літо"); *lomišče (XVI 16) "поламаний бурею ліс" (*lomiti “гнути, ламати”); *lovišče (108) “місце для полювання або рибальства; пастка" (*lovъ "полювання, лови; здобич", *loviti); *myčišče (XXI 24) “ставок”, пор. *myčiti(se) “обробляти льон гребенем” (Там само) або *mykati(sę) "чесати льон, вовну" (Там само, 35-36), така назва ставка, вочевидь зумовлена тим, що саме біля води вичісували й готували льон до миття; *nokt'išče (XXV 175) “місце для ночівлі” від *nokt’iti “ночувати” (Там само); *orišče (XXXII 162) “поле під пашею; занедбана паша" (*orti “орати”). Пор. *běliš̌̌e "місце, де відбілюють полотно" і “відбілювання полотна" від * běliti [11 т.1, с. 96].

Сему дії мають і ті локативні найменування, твірними до яких виступали віддієслівні іменники: *gatišče (ЭССЯ VI 105) “заплава; настил із тонких колод та жердин на заболочених ділянках дороги" (*gatiti, пор. *gatb “заплава"); grobišče (132) “кладовище, могила, місце поховання" (*grobъ); *kopadlišče (XII 57) "місце для купання" (*kopadlo "місце для купання"); *k qpelišče (62) "місце для купання" (*kopelb "купання, місце для купання"); *ležadlišče (XIV 157) "місце, де лежать; ложе” (автори ЭССЯ виводять це слово від *ležadlo, при цьому, однак, зазначають, що в мотивованому слові проглядається більш давній ступінь розвитку семантики твірної основи, ніж це відображено в зафіксованих продовженнях *ležadlo - див. Там само); *ležbbǐ̌če (168) “барліг” (*ležbba "барліг”); *ložišče (XVI 126) "постіль; місце для зберігання коштовностей; комора" (*lože "постіль; лігво, нора"); *orzbojišče (XXXII 249) “табір розбійників; місце розбою" (*orzbojb "розбій”) та ін.

Ряд відіменникових похідних утворено за характерними ознаками водних і земних поверхонь: *bagnišče (ЭССЯ I 125) “болотиста місцевість” від основи *bagn-, *bagno; *barišče (160) “велика калюжа, болотиста С П. І. Білоусенко, О. В. Меркулова, 2011. 
місцевість" (*bara “стояча вода"); *dolišče (V 62) “озеро; лука в низині” (*dolъ “низ”); ezerišče (VI 33) “озеро, болото, висохле озеро”; *glinišče (127) “глиняна яма; місце, яма, звідки беруть глину”; *gnězdišče (171) "місце, яке придатне для облаштування гнізда"; *morvišče (XIX 243) "мурашник" (*morvb "мураха" - Там само, 244); *oradlišče (XXXII 101) “поле, яке можна орати” (*oradlo “рало, плуг”); *orzlivišče (XXXIII 255) "низовина, залита водою; розлив річки, джерела" від *orzlivb / *orzliva "місце, де розливається річка" тощо. Пор. також топонім із непрозорою мотивацією *lojišče (XV 258) (*lojb “сало, жир”).

Серед назв такого плану трапляються поодинокі деад'єктиви *orvbnišče (ЭССЯ XXXII 222) “рівнина” від *orvbnъ “рівний”.

Низка десубстантивів іменує місцини за назвами рослин, які на ньому знаходяться, а саме: *ablonišče, *abolnišče (ЭССЯ I 42) "яблуневий сад"; *agodišče (60) "місце, де ростуть ягоди" (*agoda “плід"); *asenišče (78) “ясеневий ліс" (*asenz, *asenb); *avorišče (96) "місце, де ростуть явори"; *bobišče (II 143) "бобове поле"; *ęčmenišče (62) “ячмінне поле" (*ę̌men-, *ę̌́my) і т.ін.

Частина похідних має, поряд із локативною, темпоральну сему й позначає місце, де колись знаходилося те, що назване мотивувальним словом. Така семантика нерідко є вторинною, наприклад: *konopišče, *konopjišče (ЭССЯ Х 188) “місце, засіяне коноплею; місце, де колись було конопляне поле" (*konopja); *gordišče (VII 34-35) "городище; огорожа, укріплення; місце, де було місто; місце, де було укріплене поселення" (*gordb); *gumbnišče (VII 173) “гумно, місце для гумна або де було гумно; місце біля гумна або під ним”; *dvorišče (V 169) “великий двір; місце, де був двір"; *lozišče (XVI 121) “місце з-під виноградника або під ним” (*loza “виноградна лоза" - XVI 118); *nivišče (XXV 138) "місце, де була паша; занедбана паша"; *mytišče (XXI 79) "місце, де раніше збирали мито 3 проїжджих"; *obročišče (XXIX 94) “місце жертвоприношення; місце, де стояла церква" (*obrokъ "данина" - Там само, 98-99, назва зумовлена, очевидно, тим, що в церкві приносилися жертви божествам); *ognišče (XXXII 25) “вогнище; місце, де раніше горіло вогнище” та ін.

Інші похідні: *dbbnišče (ЭССЯ V 174) “дно, настил та обшивка; незакінчена кладка снопів” (*dzbno); *krajišče (XII 88) “віддалена окраїна; край; край посудини"; *kupišče (XIII 109) “купа сміття; місце поховання, могильний насип” (*kupa “купа, груда").

У давній руськоукраїнській мові диференціація твірних основ іменників 3 -ище на віддієслівні та десубстантивні залишилася. Дослідники стверджують, що дієслівна словотвірна модель була помітно продуктивнішою [6, с. 56-57], і творилися такі деривати, очевидно, від кореневих імен [3, с. 92]. Однак у багатьох випадках без спеціальних етимологічних досліджень неможливо визначити частиномовну належність їх первинної твірної основи [6, с. 62]. Наведені фактори 
спричинюють певну умовність у розподілі іменників зі згаданим суфіксом на групи за твірними основами, адже в ряді випадків такі іменники в XI-XIII ст. мають подвійну мотиваційну співвіднесеність. Як i в попередній період, при всій багатозначності суфікса в давній руськоукраїнській мові він найбільш чітко представлений у похідних із просторовим значенням [2, с. $5 ; 4$, с. $28 ; 6$, с. 56 ; 9, с. 50].

В обстежених текстах XI-XIII століть частина іменників успадкована 3 попередньої доби: игрище д tтемь ... был(с) (XI/XIII-XIV XA 117); ложнище (1113 СлРЯ VIII 274); донын т наречють Ду(на)ици городище Києвеиь (1118/1425 ПВЛ 10); схожахусл на игрищ(а). на плясань (10) “свято з іграми"; дворище то проклятое (1130-1156 ХД 14); ловище (1136 Сp II 38); пожни и ловища (1192 ВГ 36); гробище (XIII СДЯ II 390) "похоронна печера, гробниця" від гробъ "те саме"; мочище (1253/XVI СлРЯ IX 283) “місце з водою; місце, де мочать льон, коноплю”; ишедъ...за трі и створи ...югнища и съсоуды премногь (XI/XIII-XIV XА 141).

Трапляються й відіменникові та віддієслівні новотвори: сметьище (XI СлРЯ XXV 183) “смітник”; перев жсище б 55) "місце, де влаштовані сіті - перевесы для лову птахів"; покоище (1076 СДЯ VII 41) "місце перебування, мешкання"; и пляша на позорищи (x) (XI/XIII-XIV XA 10); поприще (1057 СлРЯ XVII 99) "міра довжини, що відповідає гр.. стадія” пов'язано 3 переть, пру “йти” [Ф III 327], утім, модель не зовсім ясна, адже в цей період дієслова попьрати з базовим значенням не фіксується (див. Ср II 1203), i, можливо, тут конфіксальний дериват [1, с. 117]; видяме ... жсертвище (XI/XVI ИФ 180) "місце приношення жертв; язичницький храм"; бывающу второму прибъжнищю

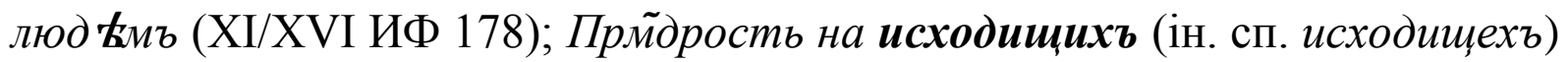
(1118/1425 ПВЛ 62); полчище (1136/1377 СлРЯ XVI 281) “місце битви” (полкъ “похід, битва" - див.докладніше: Там само 220), пор. пізніше значення цього слова - “велика кількість кого-, чого-небудь” (XII СлРЯ XVI 281); поклонище (1284 СДЯ VII 34) "місце поклоніння"; братіи на опочивищци сущуи (XIII/XV КП 37) від опочивати з втратою голосного суфікса -ва-; кладяюище (XIII/1477 СлРЯ VII 150) “місце, де був колодязь" та ін.

У праслов'янську добу починає формуватися група назв приміщень, їхніх частин, деталей інтер’єру, а саме: *krovišče (ЭССЯ ХІІІ 20) “сховище, казна, комора" (*krovъ “сховок, потаємне місце”. - Там само); *lazišče (XIV 64) “хід, вхід з підпілля” (*laziti “лазити; повзати, повзти”); *okъnišče (XXXII 44) "простір навколо вікна, віконна рама" (*okъno). Джерела XI-XIII століть, поряд із успадкованим кровище (XII-XIII СлРЯ VIII 62) “сховище, скарбниця" від кровъ “потаємне місце”, фіксують нові похідні, що називали в основному споруди релігійного призначення, а саме: коумирищю исполньшюсж (XI/XIII-XIV XА 182) “язичницький храм “від 
коумиръ “ідол”; капища идольскаг (333) “вівтар, жертовник”, це ст-сл. запозичення пов'язують з ст-сл. капъ “видиво, образ” (ЕСУМ II 372); въ стражсищи ... престависл (XI/XIII-XIV XА 372) "сторожа"; вранъ на нырищци (XII/XVI Д3 6) “руїна", ныра, нырь "башня"; молитвище (XIII СлРЯ IX 245) “місце для моління, молільня, храм”.

3-поміж праслов’янських реконструкцій натрапляємо на нечисленні соматичні назви, у більшості з них -із̌с̌е виконував, очевидно, пейоративну функцію: *golvišče (ЭССЯ VII 9-10) “голова; узголів’я”; *lъbišče (XVI 224) “великий лоб; велика некрасива голова"; nosišče (XXV 205) "великий ніс"; *očišče (XXXII 14) “очна впадина”. Давньокиївські пам’ятки засвідчують новотвір, у якому згаданий суфікс також служив для творення пейоратива: изволи л ъвою рукою срамища дьржати (XI/XIII-XIV XА 248) “статевий орган" від срамь "те саме" тощо.

Назви $n p e \partial м e m i$ в становили невелику групу. До праслов'янського періоду відносять виникнення десубстантивів зі значенням “руків'я якогось знаряддя" [7, с. 43; 11, т. 1, с. 96], наприклад: *grabišče (ЭССЯ VII 97) “граблі; руків’я граблів” (grabja, *grabji), *lopatišče (XVI 18) “руків'я лопати”; ortiišče (XXXII 212) “спис; руків’я списа", пор. *ortb “війна”, однак С.Преображенський припускає, що твірне могло означати й знаряддя боротьби - див. Преобр II 185); toporišče від toporb, *kosišče від *kosa [7, c. 43; 11, т.1, с. 96] та ін. Джерела, у яких відображено лексику XI-XIII століть, засвідчують кілька нових слів, а саме: копьище (копище) (XI/XIII-XIV СлРЯ VII 301) “древко списа";

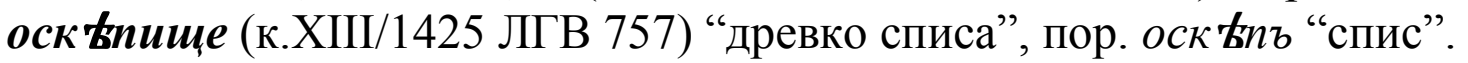

У праслов’янській мові -із̌с̌е, приєднуючись до непохідних основ, міг виконувати модифікаційну функцію, беручи участь у творенні дериватів зі значенням подібності: *ločišče (ЭССЯ XVI 132) “лукоподібний предмет” (*lokb “вид зрої”); *ojišče (XXXII 37) “передня частина плуга" від *oje “дишло” (XXXII 35). Розглянуті пам'ятки XI-XIII століть документують небагато новотворів, а саме: вретище (XII СДЯ I 498) “грубий одяг” від прасл. ver- “засовувати, ховати” [ЕСУМ I 433], це старослов'янське запозичення у давньоруській мові наведену мотивацію втратило; сви собһ оужнище (XI/XIII-XIV XА 666) “вірьовка" від оужъ, оуже “те саме"; Христосъ ... въ рубища повитъ (1130-1156 ХД 31) “грубий одяг” від рубъ "те саме".

Дослідники підкреслювали, що продуктивність суфікса -ище в давній руськоукраїнській мові була настільки велика, що його могли за зовнішньою аналогією приєднувати до непохідних іменників, котрі вже мали відповідну семантику [6, с.60]. Гадаємо, на ці процеси значною мірою вплинула висока частотність вживання слів на -ище в різних контекстах. Наприклад: земныла селыща твог (XI/XIII-XIV XА 89); собраша соудище (385); оустроиль еси и конемъ покоище (510). 


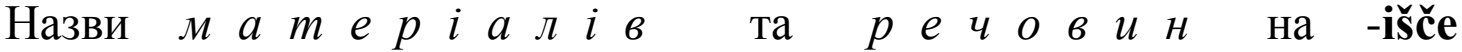
функціонували в мові давніх слов'ян, наприклад: * gnojišče (ЭССЯ VI 178) "гній, купа гною; перен. мерзенність" (*gnojb); *kališče (IX 122) “багно”;*kamenišče (131-132) “великий камінь; кам'янисте місце; скеля; купа каміння"; *krъtišče (XIII 55) "кротова грудка біля нори”; *kurišče (123) "вогнище; головешка, димом від якої обкурюють бджіл" (*kuriti “розпалювати вогонь; димитися"); *lenišče (XIV 201) "шкіра, яку скидає гадюка" (*lena / *leno "шкіра, яку скидає гадюка під час линьки"); *lenovišče (XV 111) “шкіра, яка відпадає під час линьки” (*lin'ati “линяти”) та ін. У пам'ятках XI-XIII століть засвідчене давнє утворення гноище (1076 СДЯ II 336) “купа гною; місце для скидання нечистот".

Серед $\quad a \sigma c m p a \kappa m н u x$ найменувань праслов'янської доби темпоральну семантику мають давні похідні *dbnišče (ЭССЯ V 212) “день шляху; одноденний відпочинок” (dbnb) та *godišče (VI 188) “роковини, поминки за рік по смерті людини; рік” (godb). Десубстантив днище документується й давньокиївськими джерелами: $u$ ходивще за днйще (506) “відстань, яку проходять за день”.

Найменування процесів трапляються в праслов'янській мові, наприклад: *mytišče (ЭССЯ XXI 79) “пронос" (*mytъ “пронос"); *mytišče (Там само) "вирубка" від *mytiti "очищати територію під пашу" (80), пор. також*myto "вирублена ділянка лісу".

Прозору дієслівну мотивацію має давньоруський абстракт соудщще: се $\omega(m)$ влагы на соудищи ... въпросимъ о семь (XI/XIII-XIV XA 307) “судовий розгляд”. Девербативом $\epsilon$ абстрактний іменник пръзвищ(є) (XII СНСК 323) “назва, найменування; ім’я, прізвисько”.

Деякі з розглянутих відіменникових структур і на праслов'янському, i на давньоруському грунті, нам здається, мотивувалися й дієсловами: ложити > ложе > ложище і ложити > ложище. При цьому суфікси -ище та -б конкурували, що спричинило їх стилістичне розмежування, сприяло набуттю конотативного значення суфіксом -ище.

Серед праслов'янських дериватів маємо нечисленні аугментативні назви рослин: *bermiš̌ce (I 197) “тягар” (*berm-, *bermę, *berma); *dobišče (V 92) “збільш. до *dobb” *ločišče (XVI 132) “велика лука" (*loka “лука, галявина"); “dervišče "погане дерево, погана деревина; труна" (IV 211). До пейоративів, можливо, належали десубстантиви *legovišče (XIV 99) "місце для лежання, ночівлі, лігво диких звірів" (пор. *lëgvo “лігво"); *logovišče (XV 247) “лігво" тощо. До кінця XIII століття обстежені давні руськоукраїнські тексти іменників такого плану не документують.

Функція творення n.personalia для форманта -ище не була властивою ні в праслов'янську, ні в давньокиївську добу. Етимологи реконструюють поодинокі пейоративи * dětiš̌̌ дитя; всиновлена дитина" та *l'udišče (XV 193) “дуже погана людина”, 
пор. *l'udb /*l'udb “народ”. У джерелах XI-XIII століть знаходимо лише відомий із попередніх століть дериват д қmище (1280 СДЯ III 166).

Не виключено й те, що в деяких похідних -ище міг бути надлишковим съборища жидовьска (XI/XIII-XIV XA 16); внегда аще слдеть на сонмищи съ старци (1118/1425 ПВЛ 81) “збір” від сънъмъ “те came".

Суфікс -išče уже в праслов’янській мові дав похідний -ovišče(-evišče). Його походження пов'язують із девербальною лінією, адже він перш за все виокремлювався в похідних, утворених від дієслів на -ova-, які могли мотиваційно співвідноситися не лише з дієсловами, а й твірними ранішого ступеня, що спричинило виділення сегментеми -оvišče $[6$, с. 70]. У праслов'янській мові формується група локативів 3 цим офрмантом, а саме: *ležišče / *leževišče (ЭССЯ XIV 166) “лігво (зайцЯ, сарни і т.ін.)” від *ležati; -ev- у *leževišče може бути елементом твірної основи, проте, імовірніше, входить до структури суфікса -evišče (-ovišče після м'якого приголосного) (167); *lětovišče (XV 17) “місце, де проводять літо або куди на літній період виганяють худобу" від *lěto 3 додаванням форманта -ovišče або від дієслова *lětovati “проводити літо”) тощо.

У цей же період -ovišče(-evišče) послідовно приєднувався до субстантивних основ. Не виключаємо, проте, й ад'єктивної мотивації більшості таких утворень, i тоді слід говорити про формант -із̌če, наприклад: *bobovišče (ЭССЯ II 144) “бобове поле” від *bobъ або *bobovz; *bobrovišče (144) “болотисте місце; болотистий ліс" від *bobrb (назва місцини, очевидно, зумовлена тим, що на болотах живуть саме бобри) або від *bobrovъ "бобровий”; *domovišče (V 70) “рідний дім, житло; місце, на якому стояв будинок; труна" (*domъ, *domovb); *gnojevišče (VI 177) “гнійна яма” (*gnojb, *gnojevъ “гнійний”); *gorxovišče (VII 44) “поле, на якому вирощували квасолю; горохове поле; поле, з якого прибрали горох" (*gorxz, *gorxovb); *lěsovišče (XIV 244) “лісовий заповідник” (*lěsъ, *lěsovb, *lěsovъjb "лісовий”); *logovišče (XVI 138) “лугове місце” (*logovъ “луговий”); lokovišče (147) “заросле поле” (*lokovъ “луговий”) та ін.

У джерелах XI-XIII століть розгляданий суфікс не був продуктивним, він брав участь у деривуванні небагатьох іменників 3 абстрактним або локативним значенням, наприклад: скрывають соб скровище гн \$ва (XI/XIII-XIV XA 137); и створиша в tче на торговищи (?); идеже бъ становище стою мичнку Бориса и Гл 493); л қтовище (1267 Cp II 78) співвідносне 3 лtтовати і л қто; зимовище (1267 979). Зрідка -овище виступає семантично як надлишковий елемент, наприклад: то єсть троудовище, гакоже и моужемь бываєть (1130-1156/XIII Кир 34) “хвороба" від троудъ “те саме”.

Походження вторинного суфікса -нище можна пов’язати або ж iз похідними від прикметників на $-н(u \check{u})<-b н-$, або ж, що більш вірогідно, із 
девербативними іменниками на -нъ [6, с. 73]. У давньоруській мові з цим суфіксом фіксуються поодинокі приклади: то созда ... лим tнь, рекше пристанище (XI/XIII-XIV XА 17). А. Максимова сюди відносить i тризнище [6, с. 73], що малоймовірно. Тризнище справді пов'язаний 3 тризнъ, тризна, однак походження цього іменника від дієслова *trizniti проблематичне, тим більше від тризновати, хоча етимологічно тут, напевне, корінь дієслівний [Ф IV 102]. Скоріше всього тут дієслово відіменникового походження.

Із девербальною лінією, очевидно, слід пов'язати й походження варіантного суфікса -лище. Так, I. Дулевичова пов'язує іменники типу хранилище, судилище 3 participium praeteriti на -л-, беручи до уваги, що дериваційну основу тут націлювали в часі. Мотиваційні зв'язки 3 іменниками типу хранило дослідниця вважає додатковими [10, с. 136]. Російські етимологи, навпаки, вважають іменникову мотивацію основною [3, с. 104; 6, с. 67], а відсутність імен на -ло свідчить про вживання -лище як єдиного неподільного суфікса [3, с. 104]. Нам видається також сильною позиція тих учених, котрі вважають -л- асемантичною прокладкою $[8$, с. $293 ; 5$, с. 304], звуковий характер якої так чи інакше пов'язаний 3 іменниками на -л- [8, с. 293]. Безперечним є й те, що -ище поєднується 3 дієслівними основами на приголосний, а -лище - тільки на голосний [3, с. 105; 6, с. 67], пор. игрище - игралище, усадище - с tдалище. Звертає на себе увагу те, що серед іменників на -лище більше назв вмістилищ у широкому розумінні цього слова. Наприклад: на того с вдалищи. ни икомоу ни иномоу комоу иже въ манастыри. с тсти подобаєт по ддении (60-і XI УС 117); оу своихь жсилищь лежаще (XI/XIII-XIV XA 367); вьм ъстилище (2256-1163 СДЯ II 171); свлтилище (XII Сp III 290) "храм"; виталище (1284 СДЯ I 437) "місце для проживання, житло; постоялий двір" від витати “жити, перебувати”; вълагалище (XIII СДЯ II 157) “сумка” та ін. Кілька іменників мають значення місця дії, території як адміністративної одиниці або відстані: Доброе обиталище (1106-1108/XV ХД 56) “єпархія, що знаходиться у віданні єпископа"; и ста Володимерь юб онъ поль города в лимени дали гр(а)да cm/p] флище єдино (1118/1425 ПВЛ 109) “відстань, на яку сягає постріл з лука"; въздьржсалище (1284 СДЯ II 49) “скит монахів-відлюдників”; пор.: мучилище (ХІІ СлРЯ IX 320) “місце, де мучать”; послушалище (1284 СДЯ VII 250) “місце для слухання, засідань, зборів" (послушаник "слухання" - 1076 VII 250); крестилище (XIII/XV СлРЯ VIII 42) “місце в церкві, де хрестять”.

Обстежений матеріал дає підстави стверджувати, що основна функція форманта -ище(<-із̌če) та його похідного -овище (< -оvišče/evišče) - продукування n.loci - була сформована ще в праслов'янську добу, коли ці суфікси приєднувалися до іменних та дієслівних основ і брали участь у творенні локативних найменувань (назв відкритого простору, споруд, соматичних найменувань тощо). Модифікати 3 цими афіксами 
могли мати аугментативне та пейоративне значення. Решта лексикословотвірних типів зі згаданими формантами (найменування предметів, n.abstracta та ін.) перебувала на етапі становлення. Вторинні структури нище та -лище служили для творення невеликої кількості слів на позначення місця. Висока продуктивність суфікса -ище створила підгрунтя для зростання його активності в наступні періоди розвитку мови й до утвердження його в ролі одного 3 найпродуктивніших формантів суфіксальної підсистеми українського іменника середнього роду.

Умовні скорочення використаних джерел

ВГ Вкладная Варлама Хутынскому монастирю после 1192 г. // Обнорский С. И., Бархударов И. С. Хрестоматия по истории русского языка. - [2-е изд-е.]. - Ч.1. - М., 1952. - С.36.

Д3 Слово Даниила Заточника по редакциям XII и XIII вв. и их переделкам : [Текст] / Подгот. к печати Н.Н. Зарубин. - Л. : Изд-во АН СССР, 1932. - XVI, 166 с., XIII ил.

ЕСУМ Етимологічний словник української мови / За ред. Л.С. Мельничука : у 7-и т. -Т. 1-5. - К. : Наукова думка, 1982-2006.

ИФ Мещерский Н.А. История иудейской войны Иосифа Флавия в древнерусском переводе [Текст]. - М.-Л. : Изд-во Академии наук СССР, 1958. - 578 с.

КП Абрамович Д. І. Києво-Печерський патерик. Репринтне видання [Текст]. - К. : Час, 1991. - 280 с.

ЛГВ Галицько-Волинський літопис : [Текст] // Полное собрание русских летописей. Ипатьевская летопись. - М.: Изд-во восточной литературы, 1962. - Т. II. - С.715-938.

ЛК Київський літопис : [Текст] // Полное собрание русских лето-писей. Т.2 : Ипатьевская летопись. - М. : Изд-во восточ-ной литературы, 1962.- С. 284-708.

ПВЛ Повість временних літ за Лаврентіївським списком : [Текст] // Полное собрание русских летописей. Т.1: Лаврентьевская и Суздальская летописи по академическому списку. - М. : Изд-во восточной литературы, 1962.

Преобр Преображенский А.Г. Этимологический словарь русского языка. - М. : Гос. изд-во иностр. и нац. словарей, 1959. - Т. 1-2.

СДЯ Словарь древнерусского языка (XI-XIV вв.) / Гл. ред. Р. И. Аванесов. - М. : Русский язык, 1988--2008. - T. 1-7.

СлРЯ Словарь русского языка XI-XVII вв. - М.: Наука, 1975-2008. - Вып. 1-28.

СНСК В Высоцкий С. А. Средневековые надписи Софии Киевской. - К., 1976. - 455 с.

Сp Срезневский И.И. Материалы для словаря древнерусского языка. - СПб, 1843-1912. - Т.1-3.

Ф Фасмер М. Этимологический словарь русского языка : в 4-х т.; [пер. с нем. и доп. О. Н. Трубачева]. - [4-е изд., стер.]. - М. : ООО “Издательство АСТ”, 2003.

ХА Истринъ В. М. Книгы временъныга и шбразныга Геюргия Мниха. Хроника Георгія Амартола въ древнемъ славяно-русскомъ переводь. Текстъ, изсльдованїе и словарь. - Петроградъ, 1920. - Т.1. Текстъ.

ХД Житие и хождение Даниила Русьскыя земли игумена : [Текст] // Памятники литературы Древней Руси. XII век / Вступит. статья Д.С. Лихачева ; Сост. и общая редакция А. А. Дмитриева и Д.С. Лихачева. - М.: Худ. лит., 1980. - С. 24-115.

ЭССЯ Этимологический словарь славянских языков: Праславянский лексический фонд / Под ред. О.Н. Трубачева. Вып.1-33. - М. : Наука, 1974-2007.

\section{Література}

1.Білоусенко П. І. Нариси 3 історичного словотворення (іменникові конфікси) : [монографія] / П. І. Білоусенко, І. О. Іншакова, К. А. Качайло, О. В. Меркулова, Л. М. Стовбур. - Запоріжжя-Кривий Ріг : ТОВ «ЛІПС», 2010. $-480 \mathrm{c}$.

2. Бутович 3. И. Словообразование имен существительных в новгородских грамотах XII-XV вв. / 3. И. Бутович. - Киев, 1954. - 13 с.

3. Варбот Ж. Ж. Древнерусское именное словообразование. Ретроспек-тивная формальная характеристика / Ж. Ж. Варбот. - М. : Наука, 1969. - 230 с.

4. Вдовина А.С. Связь значений действия и места в образованиях на -ище, соотнесенных с глаголами / А. С. Вдовина // Вопросы теории и истории русского словообразования. Краткое изложение докладов второй межвузовской конференции по словообразованию (март 1972 г.). - С.27-29.

5. Земская Е. А. Современный русский язык. Словообразование / Е. А. Земская. - М. : Просвещение, 1973. - $304 \mathrm{c}$. 
6. Максимова А. Л. Существительные с суффиксами -ич-, -ищ- и их производные в русском языке / А.Л. Максимова. - Л. : Изд-во Ленинградского университета, 1985. - 128 с.

7. Мартынов В. В. Праславянская и балто-славянская деривация имен / В. В. Мартынов. - Минск : Навука і техніка, 1973. - 58 с.

8. Мейе А. Общеславянский язык / Мейе Антуан; [пер. с франц., общ.ред. С.Б. Бернштейна]. - М. : Изд-во иностранной лите-ратуры, 1951. - 491 с.

9. Шелихова Н.Т. Семантика отглагольных имен существительных в древнерусском языке / Н.Т. Шелихова // Филологические науки. - 1967 - №2. - С.50-61.

10. Dulewiczowa I. Formant -ište//-isko w języku polskem i rosijskim //Studia z filologii polskiej i słowian'skiej. №15, 1976. - C.135-141.

11. Sławski F. Zarys słowotwórstwa prasłowian`skiego // Słownik prasłowian`ski. - Wrocław. Warszawa. Krakow. Gdan`sk. - T. 1-3. - 1974-1979.

12. Taszycki W. Przyrostek -isko, -is’če w językach zachodniosłowian'skich // Slavia. Sešit 2. - 1925. C. 213-227. 